\title{
Enteric coated spheres produced by extrusion/spheronization provide effective gastric protection and efficient release of live therapeutic bacteria
}

Article

Accepted Version

de Barros, J. M.S., Lechner, T., Charalampopoulos, D., Khutoryanskiy, V. V. and Edwards, A. D. (2015) Enteric coated spheres produced by extrusion/spheronization provide effective gastric protection and efficient release of live therapeutic bacteria. International Journal of Pharmaceutics, 493 (1-2). pp. 483-494. ISSN 0378-5173 doi:

https://doi.org/10.1016/j.ijpharm.2015.06.051 Available at https://centaur.reading.ac.uk/41447/

It is advisable to refer to the publisher's version if you intend to cite from the work. See Guidance on citing.

Published version at: http://dx.doi.org/10.1016/j.ijpharm.2015.06.051

To link to this article DOI: http://dx.doi.org/10.1016/j.jpharm.2015.06.051

Publisher: Elsevier

All outputs in CentAUR are protected by Intellectual Property Rights law, including copyright law. Copyright and IPR is retained by the creators or other copyright holders. Terms and conditions for use of this material are defined in the End User Agreement. 


\section{www.reading.ac.uk/centaur}

\section{CentAUR}

Central Archive at the University of Reading

Reading's research outputs online 


\title{
Enteric coated spheres produced by extrusion/spheronization provide effective gastric protection and efficient release of live therapeutic bacteria
}

\author{
Joao M. S. de Barros ${ }^{1}$, Tabea Lechner ${ }^{1}$, Dimitrios Charalampopoulos ${ }^{2}$, Vitaliy V. \\ Khutoryanskiy ${ }^{1}$ and Alexander D. Edwards ${ }^{1}$. \\ ${ }^{1}$ School of Pharmacy, University of Reading, Whiteknights, Reading RG6 6AD, UK. \\ ${ }^{2}$ Food and Nutritional Sciences, University of Reading, Whiteknights, Reading RG6 6AP, UK. \\ * Corresponding author contact details. Email: a.d.edwards@reading.ac.uk. Phone $<44>118$
} $3784253 \mathrm{Fax}+44$ (0) 1183784703 .

\begin{abstract}
We present a novel but simple enteric coated sphere formulation containing probiotic bacteria (Lactobacillus casei). Oral delivery of live bacterial cells (LBC) requires live cells to survive firstly manufacturing processes and secondly GI microbicidal defenses including gastric acid. We incorporated live $L$. casei directly in the granulation liquid, followed by granulation, extrusion, spheronization, drying and spray coating to produce dried live probiotic spheres. A blend of MCC, calcium-crosslinked alginate, and lactose was developed that gave improved live cell survival during manufacturing, and gave excellent protection from gastric acid plus rapid release in intestinal conditions. No significant loss of viability was observed in all steps except drying, which resulted in approximately 1 log loss of viable cells. Eudragit coating was used to protect dried live cells from acid, and microcrystalline cellulose (MCC) was combined with sodium alginate to achieve efficient sphere disintegration leading to rapid and complete bacterial cell release in intestinal conditions. Viability and release of $L$. casei was evaluated in vitro in simulated GI conditions. Uncoated spheres gave partial acid protection, but enteric coated spheres effectively protected dried probiotic LBC from acid for $2 \mathrm{~h}$, and subsequently released all viable cells within $1 \mathrm{~h}$ of transfer into simulated intestinal fluid.
\end{abstract}

KEYWORDS

Extrusion-spheronisation, Oral delivery; Enteric delivery; Probiotics;

ABBREVIATIONS

DLPS, dried live probiotic spheres; LBC, live bacterial cells; SIF, simulated intestinal fluid ( $\mathrm{pH}$ 7.0); SGF, simulated gastric fluid ( $\mathrm{pH} 1.8$ ); CFU, colony forming unit; GI, gastrointestinal.

\section{Introduction}

Live bacterial cells (LBC) can be administered as pharmaceuticals, nutraceuticals or food supplements, with potential to treat and prevent disease or improve health (Cook et al., 2012). Probiotics are defined by the World Health Organization (WHO) and the Food and Agriculture Organization (FAO) as "live microorganisms which when administered in 
adequate amounts confer health benefit on the host" with many proposed benefits (Bron et al., 2012; Fuller, 1991).

Although a probiotic dose of $10^{7}$ microorganisms/ $\mathrm{g}$ or $\mathrm{mL}$ is recommended to promote a beneficial host response, the required number of bacteria varies depending on the strain and application (Corcoran et al., 2008). Usually, after fermentation and harvest, a probiotic formulation starts with a cell density of $10^{9}$ colony forming units (CFU) / $\mathrm{mL}$ or $\mathrm{g}$ or higher. However, this number typically suffers significant losses during manufacturing processes, where the most detrimental step is drying, due to osmotic and oxidative shock (Fu and Chen, 2011), but dehydration is necessary for long term preservation of live bacteria in solid oral doses (Morgan et al., 2006). Furthermore, after oral administration bacterial cells must survive the natural antimicrobial human defences, such as gastric juice, bile and enzymes (de Barros et al., 2014; Edwards and Slater, 2008, 2009; Solanki et al., 2013).

Effective oral delivery of therapeutic live bacterial cells is therefore challenging.

Firstly the bacterial cells has to be delivered alive, metabolically active and in high numbers. Secondly, the formulation should offer targeting and controlled release to the site of action, which for LBC is usually the distal small intestine (typical for live bacterial vaccines) or the colon (typical target for probiotics). An increase in viability can be achieved by entrapment of the bacterial cells in a polymeric matrix that offers both acid and possibly bile protection, and is non-toxic to either the bacterial cells or the host using microencapsulation processes such as coacervation, tableting or pelletization (Cook et al., 2012). Alternatively targeting can be achieved using a polymeric coating, such as an enteric coating, to exclude gastric acid but subsequently dissolve as $\mathrm{pH}$ rises in the intestine.

Formulations that target the intestine require several features. They should be easy to swallow, allow large drug doses which could be divided into small units, give the potential of combining various active ingredients in the same unit, offer good flow properties improving capsule filling and offer a fast gastric emptying time, decreasing the residence time in the presence of detrimental gastric fluids. Enteric coated spheres fulfil these requirements. Furthermore, spheres with smooth surface morphology, high density and low friability can be individually coated, ensuring each pellet behaves as a single unit, and thus coating defects only affect a small proportion of the therapeutic dose (Abdul et al., 2010; Dukić-Ott et al., 2009).

The most common manufacturing processes to produce uniform spheres for oral administration is extrusion-spheronization as it is highly efficient and allows continuous batch process permitting a highly scalable output (Vervaet et al., 1995). A powder mixture of the therapeutic agents and excipients is wetted by adding the granulation liquid (wet granulation) with mixing until it becomes a uniform plastic mass. The wet mass is extruded through a screen or die with different lengths and diameters, forming tubular extrudates. These are then transferred to a spheronizer where they are broken down, first into small rods and after into spheroid particles as a consequence of the collision imposed by a fast spinning friction disk. Finally they are dried in either a tray or fluidized bed drier (Vervaet et al., 1995).

Drug release from spheres is composition dependent. Microcrystalline cellulose (MCC) is the excipient of choice for extrusion-spheronization as it provides ideal rheological properties, can be an excellent binder, promotes cohesiveness, and has the ability to absorb and hold large amounts of water as a result of a great porosity and large surface area (Dukić-Ott et al., 2009; Sonaglio et al., 1995). Drug release from MCC pellets is typically controlled via diffusion through the polymer matrix. However, in some cases MCC is not an appropriate excipient, for example due to chemical incompatibility, drug adsorption by MCC, 
variation of performance from different suppliers, and minimal or prolonged drug release due to delayed disintegration of MCC-based pellets (Dukić-Ott et al., 2009). Lack of disintegration may not be a major problem for many small APIs able to diffuse through the matrix, but for low-solubility drugs, large agents, and for intestinal delivery where solid formulations require enteric coating followed by rapid release on arrival to the target site, pellet disintegration is necessary. Several approaches have achieved rapid pellet disintegration and a "burst release" effect, including inclusion of disintegrants, surface active agents, co-solvents and fillers. Schroder at al showed that MCC pellet disintegration can be improved by using a solvent mixture, usually alcohol/water, as liquid binder in place of water (SchrÖDer and Kleinebudde, 1995). To ensure disintegration in LBC formulations, the amount of MCC should thus be kept low and combined with other excipients that are suitable for sphere formation, compatible with enteric delivery, have disintegrant properties, and are compatible with live bacterial cells.

Prior work demonstrated that it is feasible to produce spheres containing live bacteria by extrusion-spheronization (Bajaj et al., 2010; Brachkova et al., 2009; Huyghebaert et al., 2005a; Kim et al., 1988; Kouimtzi et al., 1997). However, none of these studies combined all necessary elements for effective LBC delivery, namely: survival during processing;

protection from gastric acid; and full disintegration to release cells after transfer into intestinal conditions. Several reports showed that LBC sphere production using extrusion-

spheronisation is feasible, but lacked study of gastric acid resistance, and no gastroprotective coating was used (Bajaj et al., 2010; Huyghebaert et al., 2005a; Kouimtzi et al., 1997). A recent study examined cell survival during production and eudragit spraycoating of MCC pellets and mini-tablets, and also studied storage stability and water content; however this did not report if these coated formulations had appropriate acid protection and cell release profiles in simulated gastrointestinal conditions (Brachkova et al., 2009).

In this study we examined whether a more sophisticated excipient blend could provide the required combination of acid resistance followed by complete release of LBC, whilst maintaining cell viability during manufacture. We combined MCC with sodium alginate, lactose and $\mathrm{CaCl}_{2}$ to formulate Lactobacillus casei as a model probiotic. We adapted a similar MCC/alginate/lactose sphere formulation that was previously developed for oral delivery and controlled release of small molecule drugs into the stomach (Sriamornsak et al., 2007). Although alginate can itself provide gastroprotection, acid still penetrates into alginate-chitosan microcapsules leading to loss of viability (Cook et al., 2013) and so we investigated if an enteric coating was also required to fully protect dried bacteria from gastric acid. A methacrylic acid copolymer type C (Eudragit L100-55), in a fully formulated coating dispersion (Acryl EZE) was spray coated onto spheres in a fluidized bed.

In many previous formulations bacteria were either freeze-dried (Brachkova et al., 2009) or thermal dried (Bajaj et al., 2010) and added to the formulation in powder form, leading to rehydration of cells followed by a second drying step. Here, for the first time we incorporated the therapeutic live bacteria directly into the granulation fluid, combined with the $\mathrm{CaCl}_{2}$ solution used to crosslink alginate.

Using this novel approach we aimed to produce an enteric coated dried live probiotic sphere (DLPS) formulation suitable for delivery of viable probiotic $L$. casei. The composition and processing parameters were optimized to produce uniform spheres with maximum viability. The spheres produced were fully characterized, determining morphological properties, disintegration profile, and survival and release of lactobacilli was monitored from uncoated and coated DLPS during simulated transit through the Gl tract. We used 
Lactobacillus casei, a model lactic acid producing bacterium that has been used in commercial products for over two decades, and has a high resistance to pharmaceutical technological processes, good in vitro human cells adherence properties and has antimicrobial effects against several Gram negative and Gram positive pathogens (Forestier et al., 2001).

\section{Materials}

Microcrystalline cellulose (Avicel $\mathrm{PH}-101)$ (MCC) was a kind gift from FMC Biopolymer (UK), Acryl-EZE was given by Colorcon (Dartford Kent, UK), sodium alginate (19 - $40 \mathrm{KDa}$ ) and calcium chloride were purchased from Sigma-Aldrich (Gillingham, UK). Lactose monohydrate (100 mesh) was purchased from DMV International (Netherlands). Lactobacilli Man, Rogosa and Sharpe (MRS) broth and agar, and phosphate-buffered saline (PBS) were purchased from Oxoid (Basingstoke, UK). The probiotic strain Lactobacillus casei NCIMB 30185 (PXN 37) was provided by Probiotics International Ltd (Protexin) (Somerset, UK).

\section{Methods}

\section{Preparation of live bacterial cell suspensions}

Single colonies of $L$. casei from MRS agar were inoculated into $10 \mathrm{~mL}$ MRS broth and incubated at $37^{\circ} \mathrm{C}$ for 24 hours to obtain cultures with an $\mathrm{OD}_{600}$ of $1.9-2.0$, corresponding to early stationary growth phase. The $10 \mathrm{~mL}$ aliquots of cells were harvested in centrifuge tubes by centrifugation $\left(3200 \mathrm{rpm}, 10 \mathrm{~min}, 4^{\circ} \mathrm{C}\right)$, the supernatants removed and the cell pellets were washed in $1 \mathrm{~mL}$ PBS and resuspended in $13 \mathrm{~mL}$ sterile $3 \%(\mathrm{w} / \mathrm{v})$ calcium chloride in deionized water to give approximately $10^{9} \mathrm{cfu} / \mathrm{mL}$. This solution was freshly prepared and used as granulation liquid.

\section{Production of uncoated DLPS formulation by extrusion-spheronisation}

A wet powder mass was prepared by mixing the powder excipients, comprising a 5:3:2 mass ratio in grams of dry reagents MCC, sodium alginate, and lactose, plus $13 \mathrm{~mL}$ granulation fluid per $10 \mathrm{~g}$ of dry ingredient (comprising L. casei suspension with $3 \% \mathrm{w} / \mathrm{v}$ $\mathrm{CaCl}_{2}$ as the granulation fluid) using an overhead stirrer. A total dry ingredient batch of $10 \mathrm{~g}$ dry ingredients - i.e. $5 \mathrm{~g}$ MCC, $3 \mathrm{~g}$ sodium alginate, and $2 \mathrm{~g}$ lactose - were pre-blended for 5 min at 50 rpm using an overhead mixer (IKA RW 20.n) with a square shape mixing arm, and subsequently wetted by gradual addition of $13 \mathrm{~mL}$ of granulation liquid, and granulated for 15 min at ambient temperature. This time was established as necessary to produce a homogeneous and cohesive plastic mass.

The mix was then extruded using a Mini Screw Extruder (Caleva Instruments, model extruder 20, UK) at a constant perforated speed of $50 \mathrm{rpm}$, using a die of 4-mm length and 1 -mm diameter, giving an L/R ratio of 4 . The angle of extrusion was $90^{\circ}$ and the barrel orientation enables the extrudate to be sampled during the process. All extrudates were spheronized at $1875 \mathrm{rpm}$ for 5 min using a laboratory scale spheronizer (Caleva Instruments MBS 120 - Multi Bowl Spheronizer, UK), having a cross-hatch plate with a diameter of 12 $\mathrm{cm}$. Wet spheres were dried in a Mini Coater Drier - 2 (Caleva Instruments, UK) at $40{ }^{\circ} \mathrm{C}$ inlet air temperature for 35 minutes. Spheres in the size range of $1.0-1.4 \mathrm{~mm}$ were collected for further experiments. Samples were taken at the end of each step to assess cell viability during the manufacturing process.

\section{Enteric coating of spheres}


Acryl-Eze ${ }^{\circledR}$ MP is a fully formulated dry enteric coating system dispersible in water. The suspension was prepared using $20 \%(\mathrm{w} / \mathrm{w})$ of powder dispersed in water. A mechanical stirrer was used to generate a homogeneous suspension. Based on the manufacturer's instructions, the suspension was agitated for $60 \mathrm{~min}$ and filtered through a $400 \mu \mathrm{m}$ sieve. Throughout the coating process the coating dispersions were continuously mixed using a magnetic stirrer. Spheres were coated in a Mini Coater Drier - 2 (Caleva Instruments, UK) using the top spray mode (nozzle diameter $0.8 \mathrm{~mm}$; atomising pressure $10 \mathrm{psi}$ ). The spray rate was $11 \mathrm{~mL} / \mathrm{h}$ for the Eudragit. For all coating experiments, the product temperature was $35^{\circ} \mathrm{C}$. Before coating, the DLPS were pre-heated to the desired product temperature during coating. During coating, the pellets were weighed until a mass gain of $20 \%$ was obtained. After coating, the pellets were left to cure in the apparatus for $15 \mathrm{~min}$ at the same conditions as the coating process to achieve complete coalescence of the polymer particles. The pellets were packed in plastic containers, sealed and stored at room temperature for characterization, or on ice for viability experiments.

\section{Water content}

The residual water content of the uncoated and coated dosage forms was determined by thermogravimetric analysis (TGA), with $5^{\circ} \mathrm{C} / \mathrm{min}$ ramp rate from $25^{\circ} \mathrm{C}$ to 200 ${ }^{\circ} \mathrm{C}$ in a TA instruments Q500 Thermogravimetric Analyzer (TA instruments, Crawley,UK).

\section{Evaluation of the DLPS - physical characterization}

\section{Size, shape and sphericity}

The size distribution influences release kinetics (Husson et al., 1992), and was screened by using a nest of sieves with aperture diameters ranging from $0.075 \mathrm{~mm}$ to 1.4 $\mathrm{mm}$ by means of a sieve particle sizer (Germany) operating at the vibrational modus of $1-3$ $\mathrm{mm}$ for $5 \mathrm{~min}$. The uncoated spheres selected for this study belonged to the fraction size from $1.0-1.4 \mathrm{~mm}$, these were collected and used for further analysis. Visual inspection of the uncoated and coated spheres was conducted using a light microscope (Leica DM2500) combined with a camera and image analysis software (ImageJ). The shape factor of the spheres is an important characteristic and generally the aspect ratio and the circularity values are used to classify their shape independent of the size, by microscopy and image analysis. For each formulation 25 spheres were randomly selected for measurement and the results presented as average \pm standard deviation.

\section{Crushing strength - Mechanical tests}

The crushing strength (the load needed to break the particles) of 25 spheres (coated or uncoated) were determined by texture analysis (Texture Analyser, Stable Microsystems, UK). Texture analysis was performed with a $P \backslash 6$ steel probe at a rate of $0.03 \mathrm{~mm} / \mathrm{s}$, using a trigger force of $0.98 \mathrm{~N}$. The crushing strength was taken at the point at which the sphere was seen to fracture on the graph of compressive force against distance.

\section{Fourier transformed infrared (FT-IR) spectroscopy}

Both non-coated and coated spheres were grounded into a fine powder using a pestle and mortar before analysis. Previous mixtures and individual powders of sodium alginate, lactose monohydrate, MCC, and Acryl-EZE were scanned at a resolution of $4 \mathrm{~cm}^{-1}$ over a wavenumber region of $500-4000 \mathrm{~cm}^{-1}$ using a Perkin Elmer 100 spectrum FT-IR spectrophotometer. 


\section{Surface morphology - Scanning electron microscopy (SEM)}

The morphology of the surface and a cross section of the coated and uncoated spheres were characterized using SEM (scanning electron microscopy). The spheres were mounted on an aluminium stub, sputter-coated with a thin layer of gold using sputter coater (Polaron, UK) under argon atmosphere, and then examined using SEM (LEO1450VP, UK).

\section{transit}

Swelling, disintegration and floatability during simulated gastrointestinal

Simulated gastric fluid (SGF) was prepared containing $0.2 \%(\mathrm{w} / \mathrm{v}) \mathrm{NaCl}$, and adjusted to $\mathrm{pH} 1.8$ with $1 \mathrm{M} \mathrm{HCl}$ chosen as the average adult gastric $\mathrm{pH}$ in the fasted state. Simulated intestinal fluid (SIF) was prepared by dissolving $0.68 \%(\mathrm{w} / \mathrm{v})$ monobasic potassium phosphate $\left(\mathrm{KH}_{2} \mathrm{PO}_{4}\right)$ in deionized water and adjusting to $\mathrm{pH} 7.0$ with $1 \mathrm{M} \mathrm{NaOH}$. Individual uncoated or coated spheres were placed into a vial containing SGF $(3 \mathrm{~mL})$ or SIF $(6 \mathrm{~mL})$ and kept at $20^{\circ} \mathrm{C}$ without shaking, and with all spheres completely submerged. For SGF, the swelling of the spheres was measured by images taken every $30 \mathrm{~min}$ for $120 \mathrm{~min}$; the spheres in SIF were measured every 10 min until disintegration. The swelling degree was then calculated using an image analysis software (ImageJ), normalizing to the initial diameter using equation 1.

$$
\text { Swelling degree }=\frac{\left(D_{t}-D_{0}\right)}{D_{0}}
$$

Where $D_{t}$ is the diameter of the spheres at time $t$, and $D_{0}$ is the diameter at time 0 . Each experiment was repeated 4 times, and the mean \pm standard deviation calculated.

The sphere disintegration in gastrointestinal solutions was evaluated by image recording. For the disintegration experiment MCC core spheres were prepared with microcrystalline cellulose as powder and water as granulation liquid, and formulated by the extrusion-spheronization method. For this experiment MCC spheres, coated and uncoated DLPS spheres $(1 \mathrm{~g})$ were placed into SGF $\left(2 \mathrm{~h}, 50 \mathrm{~mL}, 37^{\circ} \mathrm{C}\right.$, with shaking at $\left.100 \mathrm{rpm}\right)$ and SIF ( $24 \mathrm{~h}, 100 \mathrm{~mL}, 37^{\circ} \mathrm{C}$, with shaking at $100 \mathrm{rpm}$ ). The disintegration was observed by recording images every 30 min during $2 \mathrm{~h}$ in SGF, followed by transferring the spheres into $\mathrm{SIF}$ for $24 \mathrm{~h}$. In this experiment, images were taken every $30 \mathrm{~min}$ for 4 hours and then after $24 \mathrm{~h}$.

Floatability was performed by adding $1 \mathrm{~g}$ of spheres to $\mathrm{SGF}\left(50 \mathrm{~mL}, 37^{\circ} \mathrm{C}\right.$, stirring rate of $100 \mathrm{rpm}$ ) for 2 hours and the floating sphere (\%) of non-coated and coated spheres was determined by counting. Floatability is an important parameter as it helps to determine sphere behaviour, swelling, disintegration and flow in gastrointestinal solutions.

$$
\text { Floating sphere }(\%)=\frac{\text { number of floating spheres }}{\text { initial number of spheres }} \times 100
$$

\section{Survival of free and encapsulated $L$. casei in SGF}

For free cells, L. casei was inoculated in $10 \mathrm{~mL}$ MRS broth, and incubated at $37^{\circ} \mathrm{C}$ for $24 \mathrm{~h}$. After incubation and cell growth, a $1 \mathrm{~mL}$ sample was taken to determine initial cell numbers by the serial dilution and plate count method. Briefly, cells were serially diluted in vials containing PBS, and $0.1 \mathrm{~mL}$ spread onto MRS agar. Plates were incubated aerobically $\left(37^{\circ} \mathrm{C}, 48 \mathrm{~h}\right)$ and then the number of colony forming units (CFU) was counted. For survival in acid conditions, $10 \mathrm{~mL}$ aliquots of cell suspension were harvested in centrifuge tubes by centrifugation (3200 rpm, $10 \mathrm{~min}, 4^{\circ} \mathrm{C}$ ), supernatants removed and cell pellets were washed in $1 \mathrm{~mL}$ PBS followed by resuspension in either PBS (10 mL, starting cell viability) or 
simulated gastric fluid (SGF, $10 \mathrm{~mL}$, time 0 in acid) before enumeration as described above. The cells in SGF were placed in an incubator for $2 \mathrm{~h}\left(37^{\circ} \mathrm{C}\right.$, with orbital shaking at $\left.100 \mathrm{rpm}\right)$, after, an aliquot $(1 \mathrm{~mL})$ was removed for enumeration. Viable counts were determined by serial dilution in PBS followed by plating on MRS agar plates as previously described.

For uncoated and coated DLPS, samples of 3 batches of each formulation $(1 \mathrm{~g})$ were either disintegrated in PBS $(9 \mathrm{~mL})$ for calculating the starting numbers after processing, or suspended in SGF $(50 \mathrm{~mL})$ and placed in an incubator for $2 \mathrm{~h}\left(37^{\circ} \mathrm{C}\right.$, with orbital shaking at $100 \mathrm{rpm}$ ). After 2 hours the solution was placed into a stomacher (Seward Stomacher 400 circulator) for 20 minutes. Viable counts of the bacterial cells suspension were determined by serial dilution in PBS, followed by plating on MRS agar plates. Each experiment was repeated 4 times, and the mean \pm standard deviation calculated.

\section{Evaluation of the DLPS during manufacturing - cell viability}

Live cell recovery was evaluated using serial dilution of samples and agar plate colony counting after each step: slurry, mixing, extrusion, spheronization, drying and enteric coating, and during acid resistance and dissolution tests. Serial dilutions were made in PBS with a pipettor. In detail, samples of powder $(1 \mathrm{~g})$, wet mass, extrudate, or spheres were weighed into $9 \mathrm{~mL}$ of PBS and allowed to dissolve, of which $1 \mathrm{~mL}$ samples were transferred into $9 \mathrm{~mL}$ of PBS; 7 serial 10 -fold dilutions and $100 \mu \mathrm{L}$ samples of each dilution were then spread onto petri dishes of MRS agar to give dilution factors of $10^{3}$ to $10^{9}$. To determine the lowest detection limit of $10^{3} \mathrm{CFU} / \mathrm{mL}, 10 \mu \mathrm{L}$ samples were also plated directly from the rehydration medium. L. casei plates were incubated aerobically at $37^{\circ} \mathrm{C}$ for at least $48 \mathrm{~h}$. Colonies were counted and final viability expressed as colony forming unit per $\mathrm{mL}$ or $\mathrm{g}$ (CFU $/ \mathrm{mL}$ or CFU $/ \mathrm{g}$ ) calculated relative to the initial wet mass. To follow viable cell recovery after drying and exposure to simulated GI conditions, viable cell counts were expressed relative to the initial wet mass before drying. Each experiment was repeated 3 times, and the mean \pm standard deviation calculated.

\section{Protection and live cell release from DLPS formulation in simulated gastrointestinal conditions}

Uncoated and coated DLPS formulations were immersed in simulated gastric fluid (SGF) (pH 1.8, $50 \mathrm{~mL}$ ) and incubated $\left(37^{\circ} \mathrm{C}, 2 \mathrm{~h}\right.$ with orbital shaking at $\left.100 \mathrm{rpm}\right)$. Samples were taken at 1 and $2 \mathrm{~h}$ and live cell release determined, although DLPS formulations appeared to remain intact in SGF with no dissolution or cell release detected by visual inspection. After $2 \mathrm{~h}$ in SGF, formulations were removed by filtration and transferred into 100 $\mathrm{mL}$ simulated intestinal fluid (SIF) and incubated $\left(37^{\circ} \mathrm{C}, 3 \mathrm{~h}\right.$ with orbital shaking at $\left.100 \mathrm{rpm}\right)$. Samples were taken and live cell release determined at 1, 2 and $3 \mathrm{~h}$ after transfer from SGF by serial dilutions and viable count plating as described above. For each experiment the starting live cell dose corresponded to the post-drying viable cell number prior to in vitro testing of DLPS formulations. Each experiment was repeated 3 times, and the mean \pm standard deviation calculated.

\section{Statistical analysis}

Data and results are reported as mean with error bars indicating standard deviation. Statistical evaluation of comparing the significance of the difference in viability between the means of two groups was performed using a two-tailed unpaired Student's t-test; a value of $p<0.05$ was accepted as significant. 


\section{Results}

\section{Appearance, size, shape, crushing strength and surface morphology}

Prior to formulating live cells, we optimized a method to develop and produce small spherical particles by extrusion-spheronization. Drug loaded spherical particles offer great advantages, but to be effective, the final particles have to present good morphological properties. The critical characteristics of formulated coated and uncoated spheres were determined, namely appearance, size, shape, crushing strength and surface morphology (Table 1). Images of individual spheres clearly show spherical particles; this was also demonstrated by the shape measurements of the spheres. Sphericity and aspect ratio gave values between 0.9 and 1.0, indicating great spherical geometry (aspect ratio and circularity of 1.0 is ideal, as this value corresponds to the circle geometry). As expected, coating of the spheres improved their shape and surface morphology. SEM images of both formulations also confirms a spherical geometry, and indicated a difference in sphere surface morphology, with coated spheres presenting a smoother surface than uncoated spheres (Figure 2). Differences in surface morphology are apparent when the sphere surface was examined more closely by SEM (Figure $2 b$ vs $2 f)$. Furthermore, cross-section SEM photographs showed that both uncoated and coated spheres had porous cores. Also, it can be seen that the uncoated spheres had a discontinuous and porous surface. In contrast coated spheres presented an even coating layer of approximately $20 \mu \mathrm{m}$ (Figure 2). Moreover, the application of an external layer also increased the force necessary to break the coated spheres into small particles by $45 \%$ when compared to uncoated spheres showing that these spheres become stronger and denser.

The presence of the enteric polymer as a coating layer was evaluated by FT-IR spectroscopy (Figure 3). The characteristics bands of the $\mathrm{C}=\mathrm{O}$ vibrations of the carboxylic acid groups at $1705 \mathrm{~cm}^{-1}$ and of the esterified carboxylic groups at $1734 \mathrm{~cm}^{-1}$ are typical of the methacrylic acid:ethyl acrylate copolymer Eudragit L100 55, which is the main component of the fully formulated coating suspension Acryl EZE used in this study. These two bands were not detected with uncoated spheres, but were clearly detected with coated spheres, confirming the presence of Eudragit in this formulation.

\section{Swelling and disintegration of DLPS in simulated gastrointestinal fluids}

Formulated spheres were imaged in gastrointestinal solutions to evaluate the effect of sphere composition on the disintegration time, and thereby optimise formulation to achieve the requisite disintegration to fully release live bacterial cells. Spheres prepared using only MCC did not disintegrate in gastrointestinal conditions even after $24 \mathrm{~h}$ in SIF, following $2 \mathrm{~h}$ in gastric fluid (Figure 4). However, reducing the amount of MCC by half accompanied by the addition of sodium alginate and lactose resulted in sphere disintegration after $1 \mathrm{~h}$ in intestinal fluid (Figure 4). Furthermore, both uncoated and coated DLPS did not disintegrate during $2 \mathrm{~h}$ in SGF, but after $1 \mathrm{~h}$ in SIF sphere disintegration was observed, showing that the extra coating layer did not prevent sphere disintegration (Figure 4). Although coated spheres did disintegrate effectively, the enteric polymer coating did delay the onset of disintegration from around 20 minutes to around 60 minutes (Figure 5), reflecting the time required for dissolution of the enteric polymer prior to onset of disintegration. However, in spite of this delay, full disintegration was achieved which is necessary for complete release of bacterial cells.

During $2 \mathrm{~h}$ in SGF at pH 1.8 the degree of swelling of both uncoated and coated spheres was low, and neither type of sphere floated in SGF (Figure 5a). The swelling degree of uncoated spheres reached a plateau of 0.1 after 40 minutes, but in contrast, coated 
spheres showed continuous swelling in SGF during $2 \mathrm{~h}$ reaching a maximum of 0.27 , almost three times higher than the uncoated spheres. When placed directly into SIF at pH 7.0, a rapid and continuous swelling was observed until disintegration of both coated and uncoated spheres. However, uncoated spheres swelled faster and to a greater extent than coated ones, reaching a value of 0.9 after 40 minutes, nine times higher than in SGF. The coated spheres in SIF reach a maximum of 0.7 after 80 minutes, demonstrating that the coating delayed disintegration (Figure $5 b$ ).

Interestingly, when spheres were placed in SIF after being exposed to SGF for $2 \mathrm{~h}$ in order to simulate gastrointestinal passage, both uncoated and coated spheres swell less and disintegrated faster, taking 20 and 60 minutes respectively (Figure $5 \mathrm{c}$ ). These results show that the coating layer resulted in the same delay in disintegration time, 40 minutes, independent of whether the spheres were placed directly in SIF or placed into SIF after being $2 \mathrm{~h}$ in SGF. Again, the swelling was faster for the uncoated samples, but these spheres swell substantially less (0.2) compared to the ones placed directly into SIF, before they started to disintegrate. In contrast, the coated spheres' swelling was slow during 40 minutes, followed by a rapid increase in rate of swelling and then disintegration. As expected, at high $\mathrm{pH}$, fast swelling was observed for both formulations leading to mechanical damage, followed by fragmentation, which led to inaccuracy in our measurement of swelling.

Viability of $L$. casei cells during sphere production

Having established the optimal material composition and process parameters to produce enteric resistant spheres that disintegrate appropriately, we evaluated cell survival during each step of sphere manufacturing. We started by producing a granulation liquid containing LBC by mixing the overnight grown cells with $3 \% \mathrm{CaCl}_{2}$ to give an initial cell number of $10^{9} \mathrm{CFU} / \mathrm{mL}$ as this $\mathrm{CaCl}_{2}$ concentration has produced good quality spheres when sodium alginate was included in the formulation (Sriamornsak et al., 2008). As the presence of inorganic ions in solution can sometimes affect cell viability we tested $L$. casei survival after $1 \mathrm{~h}$ of exposure to various $\mathrm{CaCl}_{2}$ concentrations (1-5\%), but no loss in viability was detected (data not shown). The granulation liquid was mixed with powder excipients to form a plastic wet mass, followed by extrusion, spheronization, drying and coating. Changes in cell viability throughout the process of sphere production were expressed relative to wet mass input as residual water content varies during the process (Figure 6). From start to finish the total cell loss was no more than 1 log. While cell numbers decreased slightly during wet granulation and extrusion, no loss was detected during spheronization. The drying process was optimized to decrease the sphere moisture content to below $5 \%$ to ensure anhydrobiosis and long term cell survival during storage. This drying step itself was responsible for the greatest reduction in cell numbers, with a significant loss of $\sim 0.5$ log observed. Interestingly, sphere coating with an aqueous enteric polymer (Eudragit) solution followed by air curing did not affect cell viability. Using this extrusionspheronisation coating method, it was possible to produce DLPS with a final dose of $10^{8}$ $\mathrm{CFU} / \mathrm{g}$.

\section{Viability of $L$. casei in simulated gastric fluid}

Initial tests were conducted to investigate whether the model probiotic $L$. casei was acid resistant, and to assess the efficacy of DLPS formulations in protecting dried cells from gastric $\mathrm{pH}$ (Figure 7). When free L. casei cells were incubated in SGF ( $\mathrm{pH} 1.8$ ) a decrease in viability of $5 \mathrm{log}$ was observed after $2 \mathrm{~h}$, confirming the need for enteric encapsulation. The uncoated DLPS matrices alone enhanced the survival of the encapsulated cells by 2 log. However, after $2 \mathrm{~h}$ in SGF a significant reduction in bacterial cell numbers was still observed 
(Figure 7). Gastric acid protection was further improved by adding a thin layer ( $20 \mu \mathrm{m})$ of enteric polymer, producing coated DLPS, which completely protected $L$. casei cells from acid over a period of $2 \mathrm{~h}$, leading to no detectable loss of viability (Figure 7).

\section{Cell release in in vitro gastrointestinal conditions}

To evaluate the suitability of DLPS produced using standard pharmaceutical methods in protecting live dried LBC from gastric acid, and subsequently releasing viable cells into the intestine, spheres were tested in simulated gastrointestinal conditions ( $2 \mathrm{~h}$ in SGF pH 1.8 and $3 \mathrm{~h}$ in SIF pH $7.0,37^{\circ} \mathrm{C}$, shaking at $100 \mathrm{rpm}$ ) and cell viability determined at regular time points. Coated and uncoated DLPS containing a cell density equivalent to $10^{8} \mathrm{CFU} / \mathrm{g}$ were produced by extrusion-spheronization. Coated DLPS retained the bacteria in gastric conditions, followed by rapid sphere disintegration upon transfer to intestinal $\mathrm{pH}$ giving a burst release of viable $L$. casei cells after $1 \mathrm{~h}$, followed by a moderate slow rise over the following 3 hours (Figure 8). A complete recovery of live cell compared to the starting cell numbers of $10^{8} \mathrm{CFU} / \mathrm{g}$ was observed, indicating no loss in cell viability during 2 hours in $\mathrm{SGF}$ at $\mathrm{pH}$ 1.8. Uncoated DLPS released some cells in gastric fluid after $1 \mathrm{~h}$, with no change up to $2 \mathrm{~h}$, but again, a burst release of the majority of viable cells was observed in $1 \mathrm{~h}$ following transfer into intestinal $\mathrm{pH}$. However, uncoated DLPS failed to totally protect the cells, resulting in a loss in cell viability during gastrointestinal transit of almost 2 logs overall when compared to both the initial starting dose and to the high release of viable cells from the coated DLPS.

\section{Discussion}

The biggest challenges for formulating LBC for solid oral delivery are maintaining viability during processing, protecting fragile cells from gastrointestinal conditions such as acid, and ensuring controlled release at the appropriate intestinal site. By optimising process conditions, enteric coated spheres were successfully produced that overcame these three problems.

\section{Maintaining viability during processing}

As expected, the extrusion-spheronization process parameters and matrix composition had a significant influence on size, shape and morphology of the spheres (Newton et al., 1995; Sinha et al., 2005; Sousa et al., 2002; Vervaet et al., 1995), all of which influence the suitability of any probiotic delivery system. These parameters also affected bacterial cell viability. The formulation and manufacturing process were therefore optimised to produce MCC-Alginate-Lactose spheres with both the required physical properties but also to maximize viability of $L$. casei cells. The latter was achieved by reducing the impact of process stresses including mechanical (pressure, shear), temperature variations, or osmotic stress (e.g. during drying), each of which can affect viable cell number.

During wet granulation and extrusion surprisingly little loss in cell viability was seen, which was achieved by using mild process conditions and minimising mechanical stresses when conditions were optimised (Figure 6). In contrast to previous studies (Huyghebaert et al., 2005a; Kouimtzi et al., 1997), during the present manufacturing process no loss of viability was observed during spheronization even though a high rotation speed was used (1875 rpm). This can be attributed to protection of live cells by the excipients chosen, specifically the calcium crosslinked alginate that it is believed to have maintained the integrity of the matrix, and/or the presence of lyoprotectants such as polysaccharides in the formulation such as lactose that could protect bacterial cells by stabilizing the osmotic 
pressure and replacing water during drying (Bajaj et al., 2010; Ohtake and Wang, 2011). Indeed, this study confirmed that drying is the most challenging process step for LBC and the use of drying protectants and mild processes was critical to maintain cell viability. The final step was spray coating with an enteric polymer, which can lead to further thermal stresses if enteric coating process requires heating for example in a fluid bed during spray coating; we therefore developed coating conditions that did not impact upon cell viability. Process conditions were selected that minimised the rate of moisture penetration into the spheres, thereby reducing the likelihood of rehydrating cells followed by drying them again, which would be expected to reduce viability. The fluid bed drying temperature was also kept low $\left(35^{\circ} \mathrm{C}\right)$ to avoid thermal stresses. The application of an enteric coating to achieve gastric acid protection also resulted in a significant enhancement of the surface morphology, from discontinuous and irregular to continuous and smooth. In addition, by increasing the sphere diameter and strength it was possible to improve the resistance to crushing, whilst at the same time the release rate was not significantly reduced. Worth noting that although this process maintained high levels of $L$. casei cell viability, previous studies have identified high variation in cell survival during extrusion-spheronization between different strains (Brachkova et al., 2009), with Gram positive strains typically showing better survival than Gram negative (Kouimtzi et al., 1997). Therefore, further process optimisation will be likely required to formulate different therapeutic live bacteria to the model one used in this study.

\section{Protecting dried cells from gastric acid}

To be effective, probiotic bacteria need to be delivered alive in the distant small intestine or colon. L. casei is sensitive to acid (Figure 7), confirming that this strain is unlikely to survive passage through the stomach if not administered within a protective formulation. The addition of polysaccharides to the matrix can provide acid protection (Cook et al., 2011), which is consistent with the partial acid protection seen with the uncoated DLPS. Maximal protection from acid was only obtained for the coated DLPS, and for this formulation no significant fall in viable cell numbers was observed in 6 independent experimental repeats (Figures 7\&8). This protection was most likely achieved by the combination of two layers of acid protection; firstly the enteric polymer with a $p K_{a}$ of 5.5 which was used to coat the core incorporating the cells diminished the rate of diffusion of fluid in and out of the spheres (Siepmann et al., 2008). Secondly, the sphere core has calcium alginate in the matrix which further improved gastric acid protection because it forms an acid gel in low pHs (Cook et al., 2011). However, given the minimal swelling and lack of disintegration in acid of coated spheres, it is most likely that the enteric coating provided the majority of the protection seen, and the additional protection by the calcium-alginate containing core was not essential. However, spheres without alginate and lactose lacked the required release characteristics and so MCC alone spheres were not enteric coated and we did not measure directly the protection provided by the enteric coating alone. Furthermore, these highly dense nonfloating spheres will be most likely deposited at the bottom of the stomach, where due to their small particle size rapid gastric emptying is likely, minimizing the time in the harsh acidic environment and thus increasing cell survival (Rouge et al., 1998; Streubel et al., 2006).

The enteric coating thickness and the choice of polymer or polymer blends must be tailored to the active ingredient and target site. In a previous study, pellets were coated with several enteric polymers and various thicknesses applied to deliver layered $L$. lactis in the human ileum to help Chron's disease treatment. At pH 6.0 increasing Eudragit L30D-55 
thickness from 20 to $30 \%$, measured as mass gain, reduced the release rate of thymidine; conversely, at $\mathrm{pH}$ above 6.5 , the increase of coating thickness did not affect release rate (Huyghebaert et al., 2005b). Hung and co-workers showed that a coating level above $10 \%$ was necessary to completely cover the uneven surface of the pellets after extrusionspheronization (Hung et al., 2014). In another study using LBC loaded into pellets a coating thickness of at least $15 \%$ was necessary for complete protection from acid (Brachkova et al., 2009). Based on these observations and surface morphology of the uncoated spheres a coating level of $20 \%$ was selected to ensure total acid protection and to improve sphere morphology. Furthermore, as it was clear that the time taken before onset of granule disintegration was increased by the enteric coating, the coating thickness was chosen to ensure that the time required for sphere disintegration, was suitable to control delivery into the distal small intestine. Depending on the release site desired (i.e. distal small intestine or colon) further alteration of the enteric polymer coating thickness is possible, either to delay disintegration for colon targeting, or to allow more rapid disintegration to target the proximal small intestine.

Although the simulated gastric fluid used in this study was chosen as a mean gastric $\mathrm{pH}$ from fasting adults, the $\mathrm{pH}$ encountered after oral delivery can range considerably. However, the enteric polymer used, Eudragit L100-55, is a well characterised copolymer of methacrylic acid and ethyl acrylate (1:1 ratio) with a pKa of 5.5 , is designed to prevent acid penetration as long as the $\mathrm{pH}$ remains significantly below this $\mathrm{pKa}$, and so we expect similar protection from acid across the full range of gastric $\mathrm{pH}$ found in vivo. Furthermore gastric fluid contains additional components such as enzymes and surfactants that can have a significant impact on dissolution, penetration and disintegration of any given formulation. For these reasons, ultimately in vivo studies are required to fully establish the efficacy of live cell delivery from this formulation.

\section{Release of live cells under intestinal conditions}

There are two mechanisms of release from dried solid spheres: dissolution and/or disintegration leading to the dispersion of the matrix, or alternatively diffusion out of the matrix. For the LBC delivery matrix disintegration or complete dissolution is essential, as the micrometer size of $L$. casei cells dramatically limits diffusion rates, and live cells are unable to pass through most types of porous matrix and certainly the alginate gel used in this study, which typically has a pore size less than $200 \mathrm{~nm}$ (Gombotz and Wee, 1998). Disintegration was monitored visually, but swelling data and surface morphology also provided an insight into the mechanisms of disintegration.

The disintegration of spheres formed from MCC alone vs alginate/MCC/lactose combinations either uncoated or coated were compared to identify formulations suitable to deliver large biotherapeutic agents. Spheres formed from MCC alone failed to disintegrate (Figure 4), which ruled out this simple formulation as unlikely to release LBC, and agrees with previous studies demonstrating that higher MCC content prolongs the disintegration time, giving sustained drug release (Kilor et al., 2010; Kranz et al., 2009). Soluble sugars such as lactose, and biopolymers such as alginate are biocompatible, good pelletization agents and can promote disintegration (Dukić-Ott et al., 2009). A previous study evaluated a range of MCC quantities and established that optimal Lactobacillus survival was found with between 40 - 60\% MCC (Bajaj et al., 2010), and we found $50 \%$ MCC suitable. Crucially, although the enteric coating delayed disintegration from around 20 minutes to around 60 
minutes (Figure 5c), even when coated, the alginate/MCC/lactose blend still gave rapid and complete disintegration once the coating had fully dissolved in SIF.

In simulated GI solutions the degree of swelling can indicate firstly the structural integrity of the spheres and their ability to protect from acid (low swelling desirable) and secondly release at neutral $\mathrm{pH}$ (fast and high swelling desirable). At gastric $\mathrm{pH}(\mathrm{pH} 1.8)$ swelling was minimal and slow and spheres did not disintegrate, confirming the integrity of the enteric coating (Figure 5). The high swelling followed by disintegration in high $\mathrm{pH}$ indicates that the spheres will most likely rapidly disintegrate in the small intestine releasing the LBC, as required. Cook et al studied the swelling behaviour of probiotic alginate-chitosan coated microcapsules in various gastric $\mathrm{pHs}$ and in intestinal $\mathrm{pH}$, and at $\mathrm{pH} 2.0$ the swelling profile was similar to the results here (Cook et al., 2011), but in contrast at intestinal pH the opposite was observed with coated spheres swelling more than uncoated. In contrast to the alginate-chitosan coating used in that study, DLPS used an acrylic polymer coating that was four times thicker, which may explain the slower swelling times and should provide improved acid resistance.

SEM imaging identified cracks at the uncoated spheres surface which allow rapid solution penetration on immersion, which explains the faster swelling observed for uncoated spheres in high $\mathrm{pH}$. However, after coating a smooth surface was formed which may contribute to the far lower swelling and slower release kinetics observed with coated vs uncoated (Fig. 2, 4 and 5).

Finally, to evaluate whether the optimized DLPS formulation is suitable for intestinal delivery, cell survival and release was studied in vitro during simulated GI transit. Uncoated and coated DLPS were placed for $2 \mathrm{~h}$ in SGF and transferred into SIF for $3 \mathrm{~h}$. Although visual inspection showed no sign of disintegration, some cells were released in SGF from the uncoated spheres, but not from coated DLPS. Given the poor survival of unformulated $L$. casei in SGF (Figure 7) this is likely to be an underestimate of the number of cells actually released, since many cells released were unlikely to remain viable for long. These released cells are probably from the surface of the solid sphere or from pores in the material, and are being released during swelling and erosion. These confirm the need and suitability of the 20 $\% \mathrm{w} / \mathrm{w}$ enteric coating to achieve both total acid protection and distal intestinal release of live cells. Like gastric conditions, in vivo intestinal conditions vary significantly and many different agents are present that can not only affect sphere dissolution and disintegration, but some microbicidal agents are present that can further impact on bacterial cell viablity. For example, some dried probiotic strains and live bacterial vaccines show increased sensitivity to bile (Edwards and Slater, 2008; Mahbubani et al., 2014) For this reason, further study of cell viability in complex simulated gastrointestinal fluids and ultimately in vivo studies are essential to confirm the efficacy of this formulation for therapeutic live cell deliver.

\section{Conclusion}

The developed dried live probiotic sphere formulation represents an alternative to other oral formulations for LBC including tablets, capsules, pellets and microcapsules. Benefits of this new low-cost and scalable process include avoiding additional steps for lyophilisation of bacteria prior to formulation, use of conventional formulation equipment, increased number of live cells per dose, and reduced overall processing time. Coated DLPS effectively protected the $L$. casei cells from gastric acid and additionally delayed their release in SIF, suggesting that this formulation is ideal for efficient distal intestinal delivery of viable cells. The aim of this study was achieved, and a therapeutically relevant dose of $10^{8} \mathrm{CFU}$ of 
probiotic strain was released within $1 \mathrm{~h}$ after transfer into SIF following $2 \mathrm{~h}$ exposure to SGF. Further studies are warranted to determine the storage stability of the formulation and viable cell delivery in conditions that fully simulate GI conditions using more complex gastric and intestinal fluids, for example including enzymes and bile. Ultimately the efficacy of this oral formulation for delivery of therapeutic live bacteria and live attenuated bacterial vaccines needs to be tested in preclinical or clinical studies.

\section{Acknowledgements}

We are grateful to the University of Reading and Reading School of Pharmacy for studentship funding to JB. We thank Dr. P. Harris (Centre for Advanced Microscopy) for helping with SEM experiments, and would like to acknowledge the Chemical Analysis Facility at the University of Reading for the use of equipment and expertise.

\section{References}

Abdul, S., Chandewar, A.V., Jaiswal, S.B., 2010. A flexible technology for modified-release drugs: Multiple-unit pellet system (MUPS). Journal of Controlled Release 147, 2-16.

Bajaj, P.R., Survase, S.A., Bule, M.V., Singhal, R.S., 2010. Studies on Viability of Lactobacillus fermentum by Microencapsulation Using Extrusion Spheronization. Food Biotechnology 24, 150-164.

Blanqué, D., Sternagel, H., Podczeck, F., Newton, J.M., 1995. Some factors influencing the formation and in vitro drug release from matrix pellets prepared by extrusion/spheronization. International journal of pharmaceutics 119, 203-211.

Brachkova, M.I., Duarte, A., Pinto, J.F., 2009. Evaluation of the viability of Lactobacillus spp. after the production of different solid dosage forms. J Pharm Sci 98, 3329-3339.

Bron, P.A., van Baarlen, P., Kleerebezem, M., 2012. Emerging molecular insights into the interaction between probiotics and the host intestinal mucosa. Nat Rev Micro 10, 66-78.

Cook, M.T., Saratoon, T., Tzortzis, G., Edwards, A., Charalampopoulos, D., Khutoryanskiy, V.V., 2013. CLSM method for the dynamic observation of $\mathrm{pH}$ change within polymer matrices for oral delivery. Biomacromolecules 14, 387-393.

Cook, M.T., Tzortzis, G., Charalampopoulos, D., Khutoryanskiy, V.V., 2011. Production and evaluation of dry alginate-chitosan microcapsules as an enteric delivery vehicle for probiotic bacteria. Biomacromolecules $12,2834-2840$. 
Cook, M.T., Tzortzis, G., Charalampopoulos, D., Khutoryanskiy, V.V., 2012. Microencapsulation of probiotics for gastrointestinal delivery. Journal of Controlled Release 162, 56-67.

Corcoran, B.M., Stanton, C., Fitzgerald, G., Ross, R.P., 2008. Life under stress: the probiotic stress response and how it may be manipulated.

Curr Pharm Des 14, 1382-1399.

de Barros, J.M.S., Scherer, T., Charalampopoulos, D., Khutoryanskiy, V.V., Edwards, A.D., 2014. A Laminated Polymer Film Formulation for Enteric Delivery of Live Vaccine and Probiotic Bacteria. Journal of Pharmaceutical Sciences 103, 2022-2032.

Dukić-Ott, A., Thommes, M., Remon, J.P., Kleinebudde, P., Vervaet, C., 2009. Production of pellets via extrusion-spheronisation without the incorporation of microcrystalline cellulose: A critical review. European Journal of Pharmaceutics and Biopharmaceutics 71, 38-46.

Edwards, A.D., Slater, N.K.H., 2008. Formulation of a live bacterial vaccine for stable room temperature storage results in loss of acid, bile and bile salt resistance. Vaccine 26, 5675-5678.

Edwards, A.D., Slater, N.K.H., 2009. Protection of live bacteria from bile acid toxicity using bile acid adsorbing resins. Vaccine 27, 3897-3903. Fielden, K.E., Newton, J.M., Rowe, R.C., 1992. The influence of lactose particle size on spheronization of extrudate processed by a ram extruder. International journal of pharmaceutics 81, 205-224.

Forestier, C., De Champs, C., Vatoux, C., Joly, B., 2001. Probiotic activities of Lactobacillus casei rhamnosus: in vitro adherence to intestinal cells and antimicrobial properties. Research in microbiology 152, 167-173.

Fu, N., Chen, X.D., 2011. Towards a maximal cell survival in convective thermal drying processes. Food Research International 44, 1127-1149. Fuller, R., 1991. Probiotics in human medicine. Gut 32, 439-442. George, M., Abraham, T.E., 2006. Polyionic hydrocolloids for the intestinal delivery of protein drugs: Alginate and chitosan - a review. Journal of Controlled Release 114, 1-14.

Gombotz, W.R., Wee, S., 1998. Protein release from alginate matrices. Advanced Drug Delivery Reviews 31, 267-285.

Hung, S.-F., Hsieh, C.-M., Chen, Y.-C., Wang, Y.-C., Ho, H.-O., Sheu, M.-T., 2014. Characterizations of Plasticized Polymeric Film Coatings for Preparing Multiple-Unit Floating Drug Delivery Systems (muFDDSs) with Controlled-Release Characteristics. PLoS ONE 9, e100321.

Husson, I., Leclerc, B., Spenlehauer, G., Veillard, M., Puisieux, F., Couarraze, G., 1992. Influence of size polydispersity on drug release from coated pellets. International journal of pharmaceutics 86, 113-121. Huyghebaert, N., Vermeire, A., Neirynck, S., Steidler, L., Remaut, E., Remon, J.P., 2005a. Evaluation of extrusion/spheronisation, layering 
and compaction for the preparation of an oral, multi-particulate formulation of viable, hlL-10 producing Lactococcus lactis. European Journal of Pharmaceutics and Biopharmaceutics 59, 9-15.

Huyghebaert, N., Vermeire, A., Remon, J.P., 2005b. In vitro evaluation of coating polymers for enteric coating and human ileal targeting. International journal of pharmaceutics 298, 26-37. Kilor, V.A., Sapkal, N.P., Awari, J.G., Shewale, B.D., 2010. Development and characterization of enteric-coated immediate-release pellets of aceclofenac by extrusion/spheronization technique using kappacarrageenan as a pelletizing agent. AAPS PharmSciTech 11, 336-343. Kim, H.S., Kamara, B.J., Good, I.C., Enders, G.L., Jr., 1988. Method for the preparation of stabile microencapsulated lactic acid bacteria. Journal of Industrial Microbiology 3, 253-257.

Kouimtzi, M., Pinney, R.J., Newton, J.M., 1997. Survival of Bacteria During Extrusion-Spheronization. Pharmacy and Pharmacology Communications 3, 347-351.

Kranz, H., Jurgens, K., Pinier, M., Siepmann, J., 2009. Drug release from MCC- and carrageenan-based pellets: experiment and theory. Eur J Pharm Biopharm 73, 302-309.

Mahbubani, K.T., Slater, N.K.H., Edwards, A.D., 2014. Protection of dried probiotic bacteria from bile using bile adsorbent resins. New Biotechnology 31, 69-72.

Morgan, C., Herman, N., White, P., Vesey, G., 2006. Preservation of micro-organisms by drying; a review. Journal of Microbiological Methods 66, 183-193.

Newton, J.M., Chapman, S.R., Rowe, R.C., 1995. The assessment of the scale-up performance of the extrusion/spheronisation process. International journal of pharmaceutics 120, 95-99. Ohtake, S., Wang, Y.J., 2011. Trehalose: current use and future applications. Journal of pharmaceutical sciences 100, 2020-2053. Rouge, N., Allémann, E., Gex-Fabry, M., Balant, L., Cole, E.T., Buri, P., Doelker, E., 1998. Comparative pharmacokinetic study of a floating multiple-unit capsule, a high-density multiple-unit capsule and an immediate-release tablet containing $25 \mathrm{mg}$ atenolol. Pharmaceutica Acta Helvetiae 73, 81-87.

Saarela, M., Mogensen, G., Fondén, R., Mättö, J., Mattila-Sandholm, T., 2000. Probiotic bacteria: safety, functional and technological properties. Journal of Biotechnology 84, 197-215.

SchrÖDer, M., Kleinebudde, P., 1995. Development of Disintegrating Pellets Obtained from Extrusion/Spheronization. Pharmacy and Pharmacology Communications 1, 415-418. 
Siepmann, F., Siepmann, J., Walther, M., MacRae, R.J., Bodmeier, R., 2008. Polymer blends for controlled release coatings. Journal of Controlled Release 125, 1-15.

Sinha, V.R., Agrawal, M.K., Kumria, R., 2005. Influence of formulation and excipient variables on the pellet properties prepared by extrusion spheronization. Curr Drug Deliv 2, 1-8.

Solanki, H.K., Pawar, D.D., Shah, D.A., Prajapati, V.D., Jani, G.K., Mulla, A.M., Thakar, P.M., 2013. Development of Microencapsulation Delivery System for Long-Term Preservation of Probiotics as Biotherapeutics Agent. Biomed Res Int 2013, 620719.

Sonaglio, D., Bataille, B., Ortigosa, C., Jacob, M., 1995. Factorial design in the feasibility of producing Microcel MC 101 pellets by extrusion/spheronization. International journal of pharmaceutics 115, 5360.

Sousa, J.J., Sousa, A., Podczeck, F., Newton, J.M., 2002. Factors influencing the physical characteristics of pellets obtained by extrusionspheronization. International journal of pharmaceutics 232, 91-106. Sriamornsak, P., Nunthanid, J., Luangtana-anan, M., Puttipipatkhachorn, S., 2007. Alginate-based pellets prepared by extrusion/spheronization: A preliminary study on the effect of additive in granulating liquid. European Journal of Pharmaceutics and Biopharmaceutics 67, 227-235.

Sriamornsak, P., Nunthanid, J., Luangtana-anan, M., Weerapol, Y., Puttipipatkhachorn, S., 2008. Alginate-based pellets prepared by extrusion/spheronization: Effect of the amount and type of sodium alginate and calcium salts. European Journal of Pharmaceutics and Biopharmaceutics 69, 274-284.

Streubel, A., Siepmann, J., Bodmeier, R., 2006. Gastroretentive drug delivery systems. Expert opinion on drug delivery 3, 217-233.

Temmerman, R., Pot, B., Huys, G., Swings, J., 2003. Identification and antibiotic susceptibility of bacterial isolates from probiotic products. Int $\mathrm{J}$ Food Microbiol 81, 1-10.

Thoorens, G., Krier, F., Leclercq, B., Carlin, B., Evrard, B., 2014. Microcrystalline cellulose, a direct compression binder in a quality by design environment-A review. International journal of pharmaceutics 473, 64-72.

Trivedi, N.R., Rajan, M.G., Johnson, J.R., Shukla, A.J., 2007.

Pharmaceutical Approaches to Preparing Pelletized Dosage Forms Using the Extrusion-Spheronization Process. 24, 1-40.

Vervaet, C., Baert, L., Remon, J.P., 1995. Extrusion-spheronisation A literature review. International journal of pharmaceutics 116, 131-146. Wohlgemuth, S., Loh, G., Blaut, M., 2010. Recent developments and perspectives in the investigation of probiotic effects. International Journal of Medical Microbiology 300, 3-10. 
Table 1

\begin{tabular}{|c|c|c|}
\hline Parameter & Uncoated spheres & coated spheres \\
\hline \multirow{2}{*}{ Appearance } & $\begin{array}{c}\text { Spherical, slight yellow, } \\
\text { with a rough surface }\end{array}$ & $\begin{array}{c}\text { Spherical, white, with a } \\
\text { smooth surface }\end{array}$ \\
\cline { 2 - 3 } & & \\
\hline Aspect ratio & $0.92 \pm 0.05$ & $0.94 \pm 0.05$ \\
\hline Circularity & $8.26 \pm 1.53$ & $0.99 \pm 0.02$ \\
\hline Crushing strength & & $11.90 \pm 1.37$ \\
\hline
\end{tabular}

Table 1. Appearance, shape (aspect ratio, circularity) and crushing strength of DLPS with or without coating.

Figures

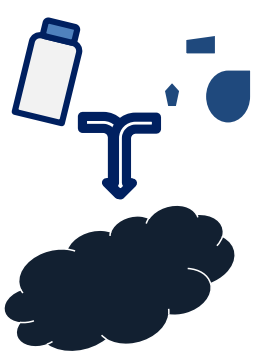

Granulation

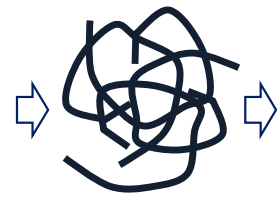

Extrusion

Figure 1

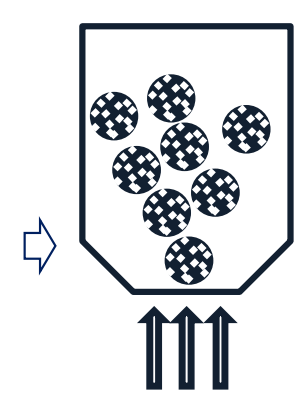

Drying

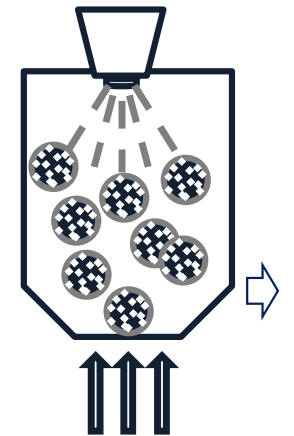

Enteric coating

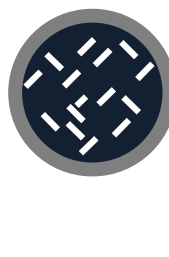

Coated DLPS

Figure 1. Concept and experimental work - Production of Dried Live Bacterial Spheres (DLPS) by extrusion- spheronization. 


\section{Figure 2}

Uncoated

Coated

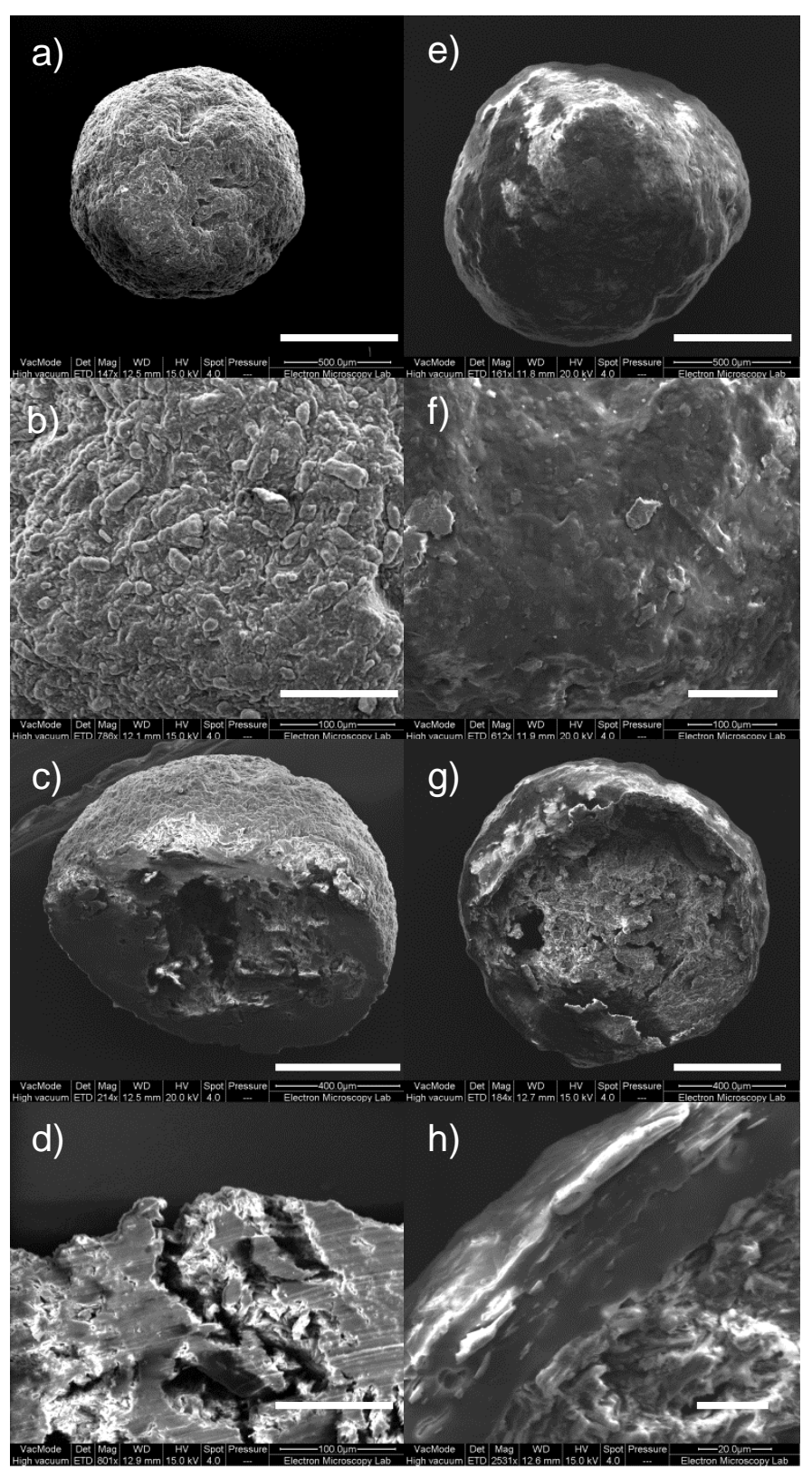

Figure 2. Scanning electron micrographs of DLBS. The surface morphology (a, b, e, f) and interior (c, d, g, h) were examined by SEM. Uncoated spheres: a) uncoated sphere (bar=500 $\mu \mathrm{m})$; b) surface morphology of uncoated sphere (bar=100 $\mu \mathrm{m})$; c) interior of uncoated sphere (bar $=400 \mu \mathrm{m}) ; \mathrm{d}$ ) cross-section of surface of an uncoated sphere (bar $=100 \mu \mathrm{m})$. Enteric coated spheres: e) enteric-coated sphere (bar $=500 \mu \mathrm{m})$; f) surface morphology of enteric-coated sphere (bar=100 $\mu \mathrm{m}) ; \mathrm{g}$ ) interior of enteric-coated sphere $(\mathrm{bar}=400 \mu \mathrm{m})$; h) cross section of a coated sphere showing coating and interior (bar=20 $\mu \mathrm{m})$. 
Figure 3

Uncoated

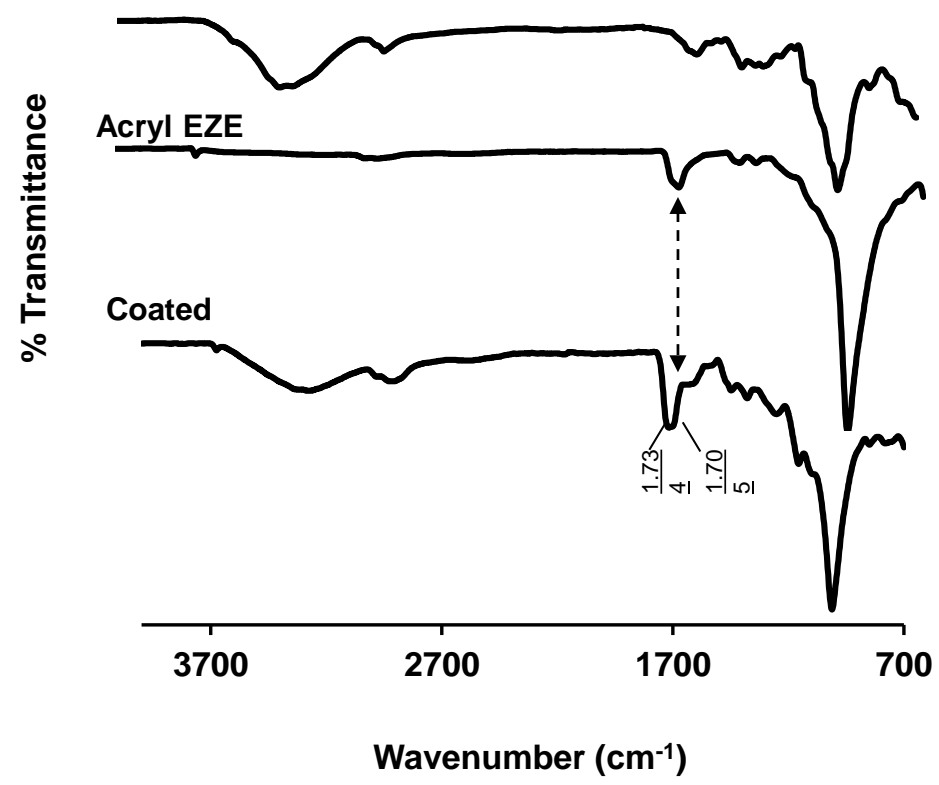

Figure 3. FT-IR spectra of the enteric polymer (Eudragit), uncoated and coated spheres.

a)

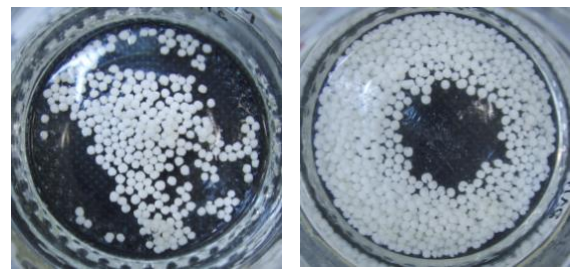

Figure 4

b)
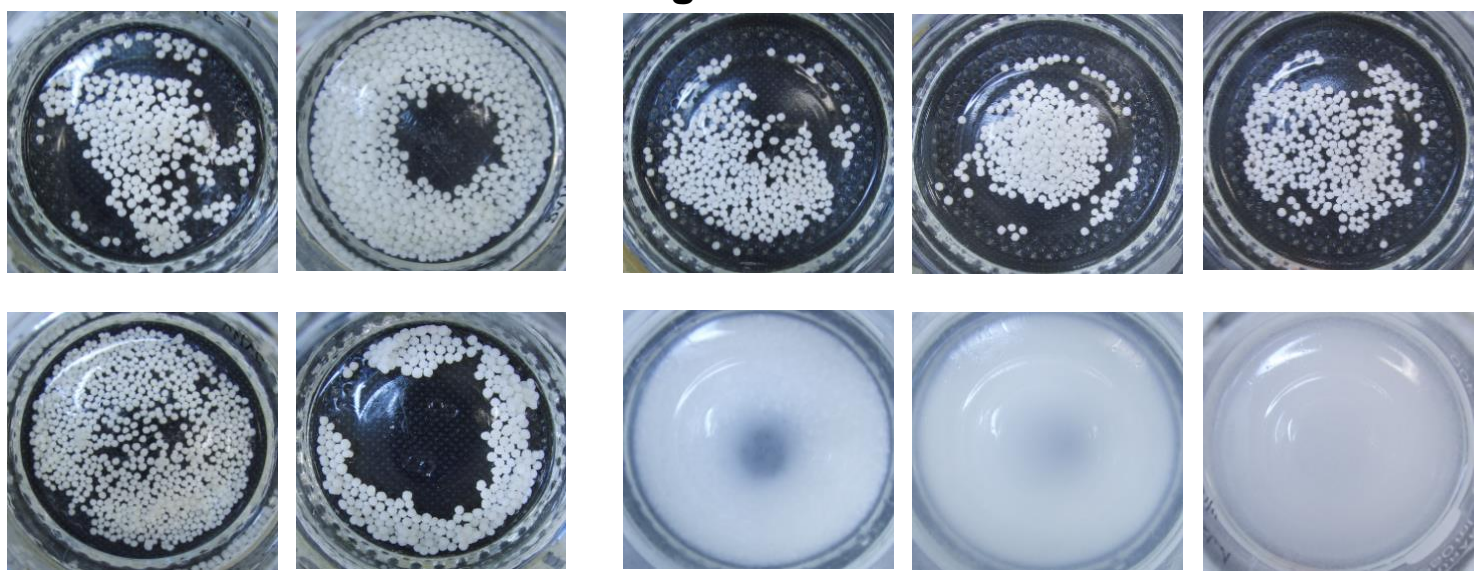

c)
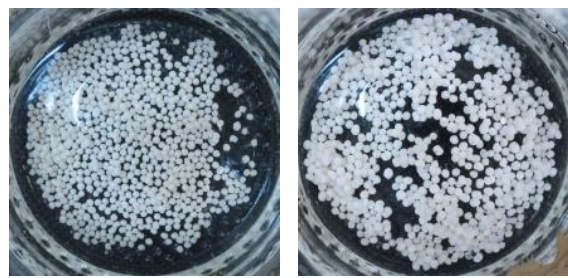

$\mathrm{Oh}$

$2 \mathrm{~h}$

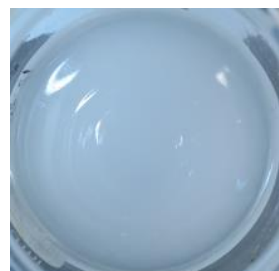

$1 \mathrm{~h}$

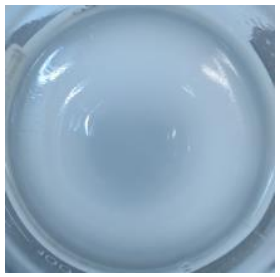

$3 \mathrm{~h}$

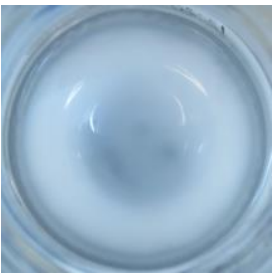

$24 \mathrm{~h}$

SGF

Figure 4. Disintegration of (a) MCC; (b) uncoated and (c) coated DLPS in simulated gastrointestinal conditions. $L$. casei cells were encapsulated into MCC, uncoated and coated DLPS. These formulations were exposed to simulated gastric conditions by immersion in SGF for 2 hours, filtered and transferred into SIF for 24 hours. Images were taken at different time points to observe disintegration and degree of swelling. Similar results were observed in 3 different experiments. 


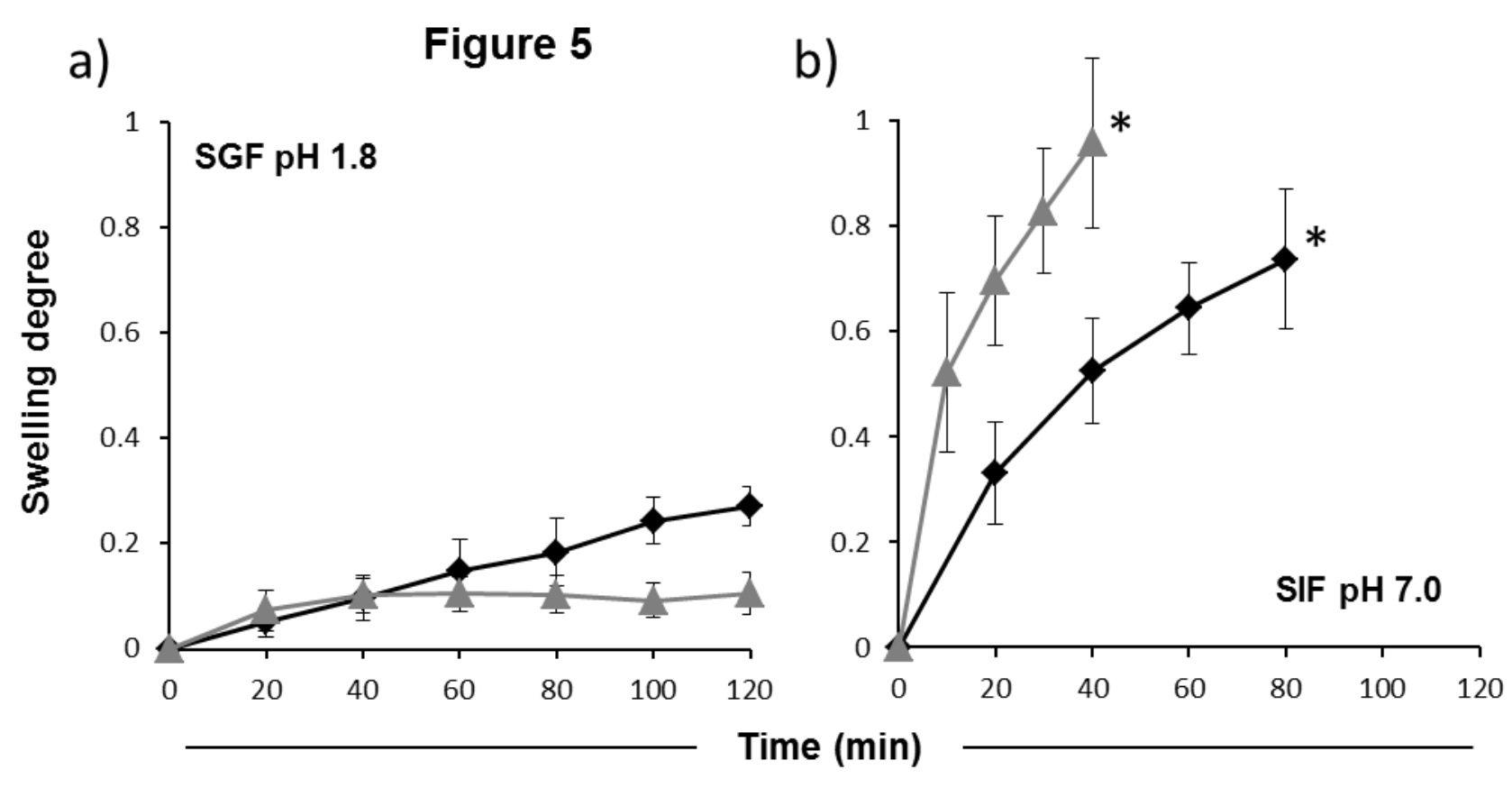

c)

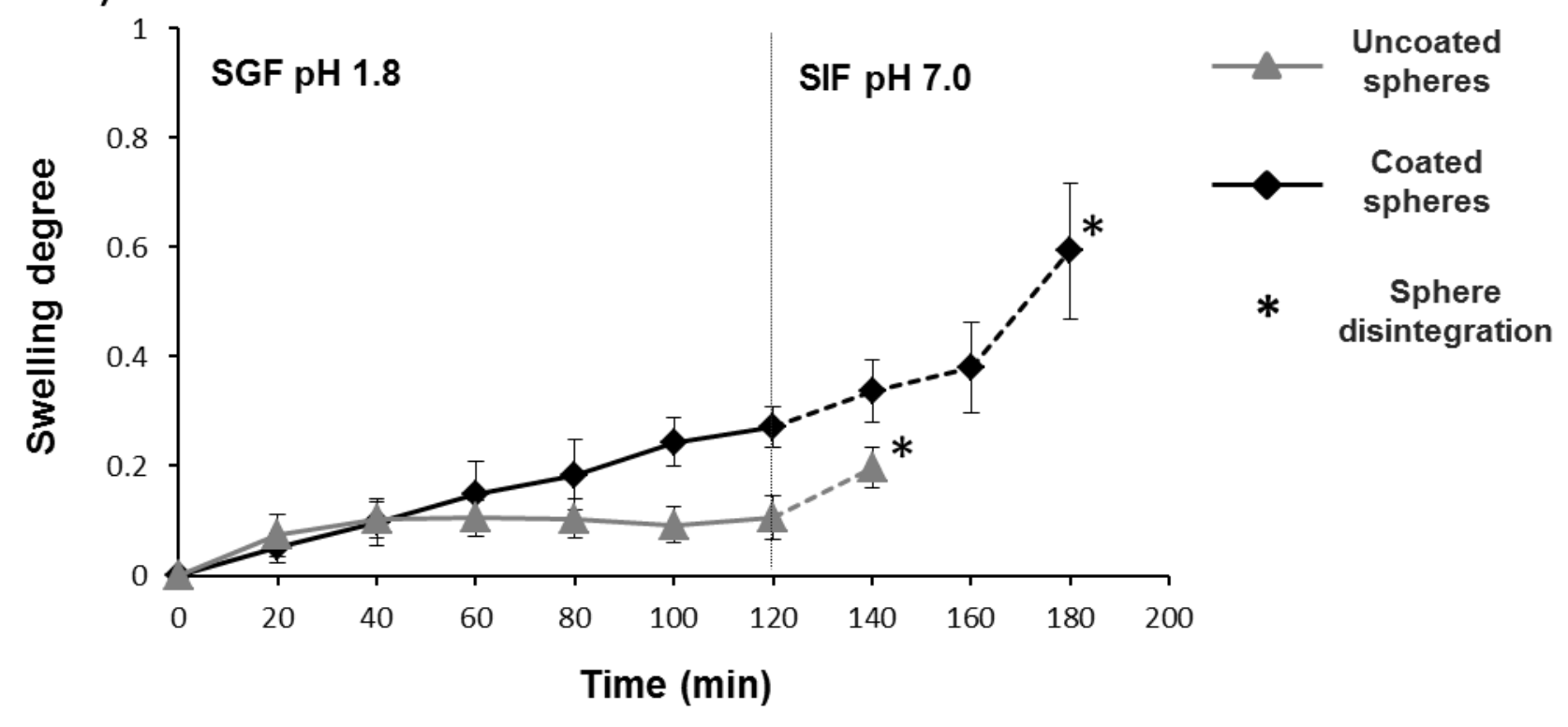

Figure 5. Swelling behaviour of uncoated (triangle) and coated (diamond) DLPS in gastrointestinal solutions, $\left(^{*}\right)$ disintegration of the spheres. DLPS were placed either directly in SGF ( $\mathrm{pH} 1.8,2 \mathrm{~h}$ ) and SIF ( $\mathrm{pH} 7.0$, until disintegration) or in SIF follow 2 hours in SGF. Images were taken at different times and swelling assessed. Results are representative of 4 repeats (mean \pm standard deviation). 


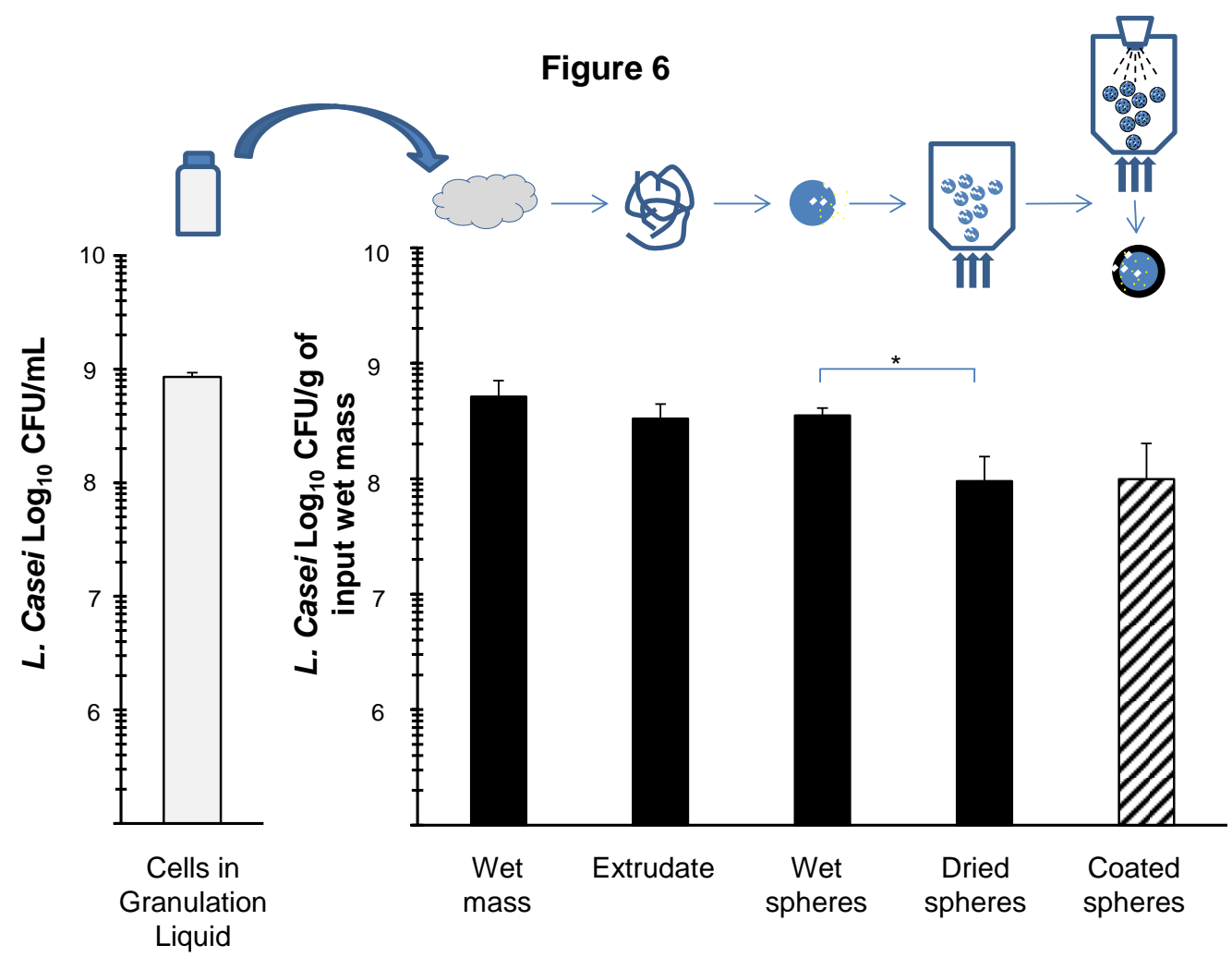

FIGURE 6. Cell viability during manufacturing process. L. casei cells were grown overnight, resuspended in $\mathrm{CaCl}_{2}$, mixed with the formulation components in an overhead stirrer for $15 \mathrm{~min}$, extruded at $50 \mathrm{rpm}$ through a $4 \mathrm{~mm}$ radius/ $1 \mathrm{~mm}$ diameter die, spheronized at $1875 \mathrm{rpm}$, dried at $40^{\circ} \mathrm{C}$ for $35 \mathrm{~min}$ in a fluid bed dryer and enteric coated until $20 \%$ mass gain was achieved. Survival was tested by comparing the direct release of cells from each process step into simulated intestinal fluid (SIF) and cell counts adjusted to wet mass water content. * $p<0.05$. Viable cell recovery was significantly reduced by drying $(p<0.05)$. Data represent mean values and error bars indicate standard deviation $(n=3)$.

Figure 7

Figure 7. Survival of free and encapsulated $L$. casei cells in simulated gastric conditions. $L$ casei cells were resuspended in simulated gastric fluid, $\mathrm{pH} 1.8$ and incubated for 2 $\mathrm{h}$. At time $0 \mathrm{~h}$ and $2 \mathrm{~h}$ after challenge samples were taken and viability assessed. *: $p<0.05$. Viable cell recovery was significantly reduced by acid conditions compared to time $0 \mathrm{~h}$ ( $p$ $<0.05)$. Results are representative of 3 repeats (mean \pm standard deviation).

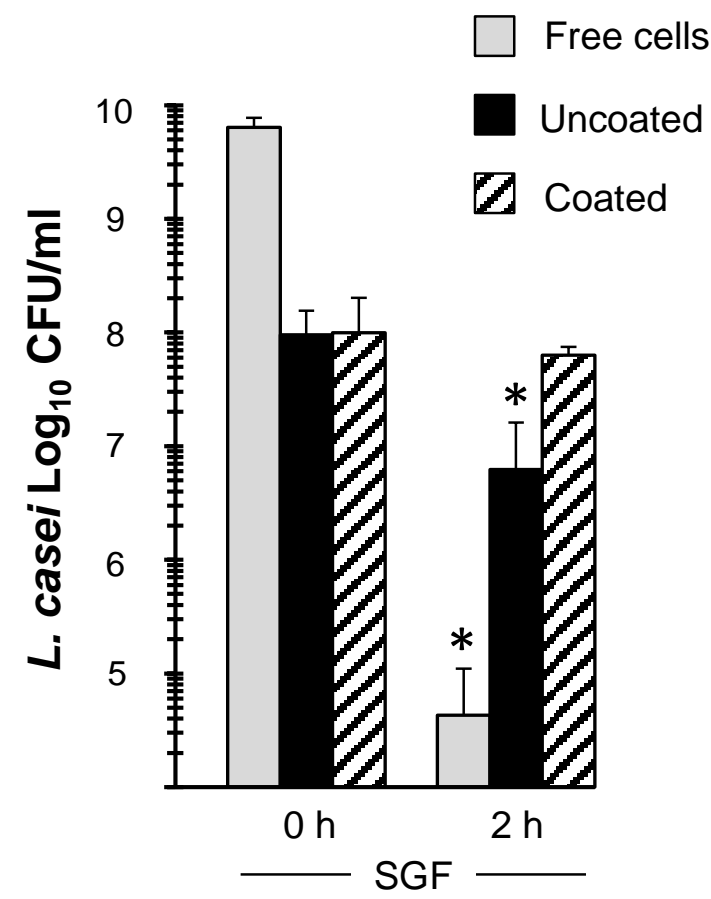


Figure 8
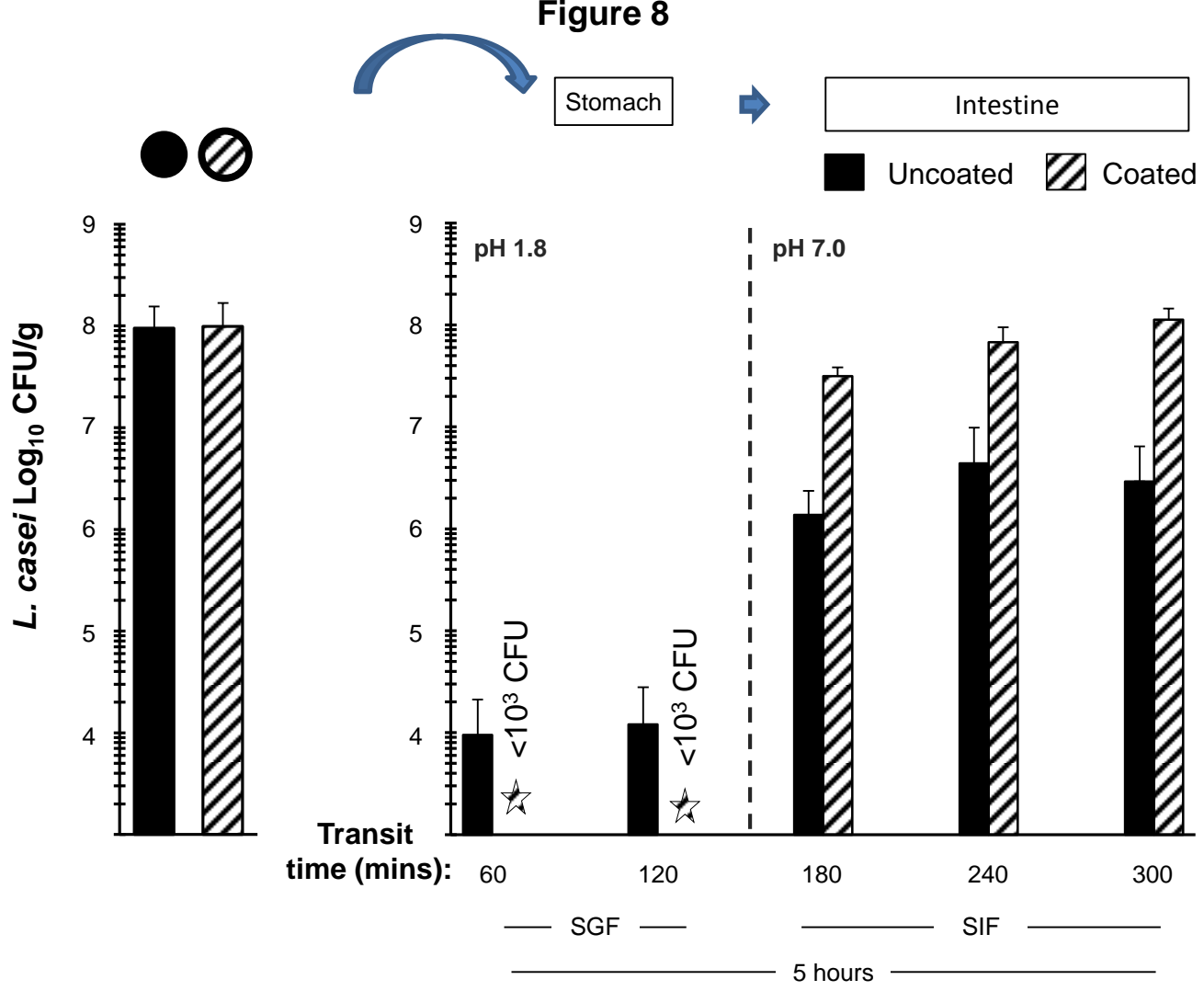

FIGURE 8. Controlled delivery of probiotic live bacterial cells from DLPS in simulated gastrointestinal conditions. $L$. casei cells were prepared using the process described in Figure 7 and DLPS were made with no coating or with $20 \%$ mass gain of enteric coating. To mimic gastrointestinal passage DLPS were immersed in SGF for 2 hours followed by transfer into SIF for 3 hours and viable cell recovery determined at indicated time points. Similar recovery and kinetics were observed in 3 different experiments. 